\title{
A Feminist Analysis of Jane Eyre \& Pride and Prejudice
}

\author{
Lili $\mathrm{Lu}^{1, \mathrm{a}}$, Youbin Zhao ${ }^{2, \mathrm{~b}}$ \\ ${ }^{1}$ School of Translation Studies, Jinan University, Zhuhai City, Guangdong Province, P.R. China \\ ${ }^{2}$ School of Translation Studies, Jinan University, Zhuhai City, Guangdong Province, P.R. China \\ alulili0125@qq.com, byoubinz@jnu.edu.cn
}

\begin{abstract}
Keywords: Feminism; Jane Austen; Pride and Prejudice; Charlotte Brontë; Jane Eyre
\end{abstract}
\begin{abstract}
Both Jane Austen and Charlotte Brontë are distinguished writers in the literary history, especially significant women writers in the18th-19th century of England. Jane Austen played a pioneering role in the generation of English female literature, and Charlotte Brontë further developed feminist thoughts. By analyzing female roles in Pride and Prejudice and Jane Eyre from feminist perspective, this paper will compare these two women writers' feminist thoughts.
\end{abstract}

\section{Introduction}

Virginia Woolf once said: "A woman must have money and a room of her own if she is to write fiction." ${ }^{[1]}$ (Woolf, 1989, 2) In this sentence, "money" and "room" do not only mean themselves, but the realistic portraiture that there was no economic basis, no literary tradition or creative freedom for women to write works. For a long period, women, under the repressive of patriarchy culture, had been existed as "the second sex". In social life, women were underprivileged, and men were subject to a lifetime of slavery. Women did not have the equal rights on employment and pay, the right to receive education or even the right of succession. Economic dependence forced women to attach themselves to men. From the social point of view, women in Victorian Britain were scraps if they could not get married. To men, the social productive laborers, housekeeping and childcare were missions of women. Women were called "decorations in the living room" and "angels in the kitchen". In the thousands years of English literature history written by men, women were the object of observation and fantasy, wearing the mask of "angel" or "demon" reluctantly. Women had long been discriminated and even detested.

However, at the end of the eighteenth century, middle-class women began to write literary works. And at the latter part of the nineteenth century, English women writers came forth in great number. In their works, female roles became free individuals instead of serving as accessories of male roles. They got flesh and blood, independent dignity and vivid characteristics. They did not exist as the reference or a compensation to men. They were who they were supposed to be. Among these numerous women writers, Jane Austen and Charlotte Brontë are iconic. In what follows, the paper will analyze Pride and Prejudice and Jane Eyre from feminist perspective.

\section{Womanhood Under the Feminine Principle Sight}

\subsection{Independent Personality}

Simone de Beauvoir once pointed out that to be feminine is to appear weak, futile, and docile. The young girl is supposed not only to deck herself out, to make herself ready, but also to repress her spontaneity and replace it with the studied grace and charm taught her by her elders. ${ }^{[2]}$ (Beauvoir, 1998, 387)

In Pride and Prejudice, Jane Bennet is of such a gentle and kind nature; Georgiana Darcy is shy, introverted and versatile; Miss Bingley is a fine woman "with an air of decided fashion" ${ }^{[3]}$ (Austen, 2003, 6) They all meet the demand that women should be meek and mild-mannered, possessing some "useful" skills to please men. They are "angels" of men's eye. On the contrary, Elizabeth loves "useless" reading, and she is intelligent and lively with good self-esteem. Her response to Darcy's first confession with arrogant tone is "why with so evident a design of offending and insulting me you 
chose to tell me...” ${ }^{[3]}$ (Austen, 142) She discards and resists old traditions and ideas. To look after her

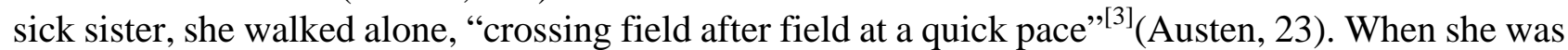
shown in front of the gentlefolk, her appearance, her "weary ankles, dirty stockings" ${ }^{33}$ (Austen, 23) created a great deal of surprise. She takes delight in anything ridiculous. When she was told that "A woman must have a thorough knowledge of music, singing, drawing.... certain something in her air and manner of walking, the tone of her voice..." she mocked: "I am no longer surprised at your knowing only six accomplished women. I rather wonder now at your knowing any." "3] (Austen, 28) All these have shown that Elizabeth is longing to own independent utterance right and her demand to express individuality.

In Jane Eyre, women are supposed to be very "calm” generally, too. However, Jane Eyre thinks "women feel just as men feel; they need exercise for their faculties, and a field for their efforts as much as their brothers do..., ${ }^{[4]}$ (Brontë, 2003, 101) Therefore, when Jane Eyre first met Mr. Rochester with his injured foot, she got him out of trouble though the latter really doubted whether the small girl owned such capability. She is always in revolt against her lot. Though she was conscious that a moment's mutiny had already rendered her liable to strange penalties, she still wrestled with John, the "tyrant" and "murderer". She accused Mrs. Reed of maliciousness and insincerity, crying out: "People think you a good woman, but you are bad, hard-hearted. You are deceitful." "4] (Brontë, 30) Jane Eyre dares to love and hate, and rebels against the injustice of which she is a victim.

Both Elizabeth and Jane Eyre have shown self-respect, self-reliance. They scorn conventions made by patriarchal society. Both Jane Austen and Charlotte Brontë did not gift their heroines with stunning beauty, but we audiences are attracted by Elizabeth's and Jane Eyre's charms and resist spirit. Their rebellions manifest outer beauty is not women's first task, and compliance can never embody their true values. Women should have independent personality.

\subsection{The Appearance of Heroines}

Simone de Beauvoir once pointed out that by compliment and blame, little girl understands the meaning of "beauty" and "ugliness"; she soon understands the point of being likable is that she must be good in attractive and charming looking. ${ }^{[2]}$ (Beauvoir, 322) In patriarchal society, appearance is one of the most important criteria of good women. Therefore, in a great number of traditional literature works, heroines are shinning and gorgeous.

However, as Mr. Bennet said, Elizabeth is "not half so handsome as Jane, nor half so goodhumoured as Lydia"[3] (Austen, 2). Mr. Darcy bluntly said she is not handsome enough to tempt him. Elizabeth may not be good in appearance, but she is thought to be "tolerable" in Darcy's eye. According to Mr. Bingley, she is "very pretty and very agreeable". Therefore, she is still in the acceptable range. However, Jane Eyre is plain and little. Mr. Rochester's comment on Jane Eyre's appearance is that she has "rather the look of another world", and he even marvelled where Jane Eyre had got "that sort of face". ${ }^{[4]}$ (Brontë, 113) Brontë gave Jane Eyre a rough exterior deliberately, which is subversion of heroines' images in traditional literature works, and a rebellion against the women's standard in patriarchal society. Brontë hoped what deeply touched audience was Jane Eyre's inner spirit instead of her outside. Though there is no contradiction between good appearance and wisdom or independent personality. Since ancient times, there has been no lack of distinguished women with exquisite features.

\section{Love View Under the Feminine Principle Sight}

\subsection{True Love: Foundation of Marriage}

As Simone de Beauvoir pointed out, being spinsterhood makes a maiden become a parasite or an untouchable. Getting married is the only way for her to get support, and the only reason to explain why she should survive. ${ }^{[2]}$ (Beauvoir, 489)

In Pride and Prejudice, Charlotte married Mr. Collins because she was at the age of twenty-seven, because "it was the only honourable provision for well-educated young women of small fortune, and however certain of giving happiness, must be their pleasantest preservative from want." ${ }^{\text {,3] }}$ (Austen, 93) As Camelot said, if a girl is unlucky or is not at an advantage ... she can only keep silent; when the 
time is right, she should hold it tightly and thank God. ${ }^{[2]}$ (Beauvoir, 494) But in Elizabeth’s opinion, it was impossible for Charlotte to be tolerably happy in the lot she had chosen because there was no love between her and Collins.

Both Elizabeth and Jane Eyre think the foundation of marriage is true love instead of fame or fortune, which is the shining point and the greatness of these two fictions. Therefore, Elizabeth declined Mr. Collins's declaration though he could provide her with a good life. For the same reason, Jane Eyre refused Mr. St. John, a missionary just in want of a wife missionizing with him. Both Elizabeth's and Jane Eyre's love is pure, never mixed with secular benefit. And they long for their marriage is pure, too. Because they believe without true love, they can never get happiness in marriage.

\subsection{Equality and Mutual Respect}

When Darcy showed his love to Elizabeth for the first time, "his sense of her inferiority--of its being a degradation--of the family obstacles ... seemed due to the consequence he was wounding."[3] (Austen, 141) His proud words harmed Elizabeth's pride and aroused her resentment. She refused him because she asked for the respect from men.

When Jane Eyre thought Mr. Rochester would marry Miss Ingram, she decided to leave. She retorted: "Do you think I can stay to become nothing to you? Do you think I am an automaton? ... it is my spirit that addresses your spirit; just as if both had passed though the grave, and we stood at God's feet, equal--as we are!" "4] (Brontë, 240) Jane Eyre puts a high value on equality in personality and emotional connection. Therefore, when Jane Eyre learned the existence of Mr. Rochester's wife, the madwoman in the attic, she left Thornfield Hall decisively.

\subsection{The Concept of Equality}

Different from Charlotte Brontë, Jane Austen did not emphasize complete equality between men and women. Jane Austen's ideas about gender equality are relatively conservative. What she asked for is just women have the respect from men. Therefore, Jane Eyre showed better self-esteem than Elizabeth. But the equality Brontë asked for is somewhat extreme. In the end of the story, Jane Eyre got a fortune of twenty thousand pounds and she became rich and independent, while Thornfield Hall was burnt to the ground with such an immense quantity of valuable property destroyed. Mr. Rochester had nothing but "one eye knocked out, one hand so crushed that the surgeon had to amputate it directly, and the other eye inflamed: he lost the sight of that also". ${ }^{[4]}$ (Brontë, 413) Jane Eyre finally served both for his prop and guide. She achieved so-called full equality, which actually showed Jane Eyre's or Charlotte Brontë's self-abasement.

This kind of ideas make Charlotte Brontë a radical feminist advocating "female as superior" and "men were the enemy", though it is subversion of the conventional androcentric concept, with women depicted as disadvantaged. As Emma Watson's speech in United Nations, "it is time that we all perceive gender on a spectrum not as two opposing sets of ideals ... If we stop defining each other by what we are not and start defining ourselves by what we are--we can all be freer." Feminism should not be just about trying to protect women, and build a matriarchy society. What is different between a matriarchy society and a patriarchy society? When there is no more superior or inferior, equality will come as a natural consequence.

\section{Spirit of Resistance}

As mentioned before, both Elizabeth and Jane Eyre were the figures of new women with the rebellious spirit. Elizabeth felt contempt for gentlewoman-training catering to men's taste. She loves reading and expressing her original insights. She discarded the convention that a lady should be elegant and well-groomed... Jane Eyre's resistance to injustice is even fiercer. She fought against John, Mrs. Reed and Lowood School... She fought against the unfairness of her destiny. Jane Eyre is like a warrior, never bending over.

However, another character attracted attention. It is the madwoman in the attic, Bertha. Rochester, the hero of this novel is the center of right, married Bertha for a fortune of thirty thousand pounds and 
her beauty. Rochester did not treated her well but imprison her in the attic. He insulted her with dirty and filthy words. He described her as "low, narrow, and singularly incapable of being led to anything higher". He called her "demon". He blamed her for his disastrous marriage, forgetting that Bertha was also a victim of him, of her family, of the patriarchal society. Bertha is the other side of Jane Eyre. Her action of burning Thornfield Hall shows Jane Eyre's latent desire of fighting against the center position of Rochester, of men, representing women destroying patriarchy. The madwoman in the attic is the symbolic of women's repressed creativity. She is the embodiment of the rebellious writer. ${ }^{[6]}$ (Zhang, 1998, 80)

In Jane Eyre, she had five revolts. The first is to burn Rochester, the man did not love her but tortured her, imprisoned her, in his bed, which is her struggle against the oppression of the authority of her husband. The second is to bite and stab her brother, which shows her hatred of her family and patriarchy. The third is to pay a "ghastly" visit to Jane Eyre, tearing up Jane's wedding dress, throwing it on the ground and stamping it, which implies Bertha's resentment against marriage on the basis of money. The fourth happened when her existence was exposed, Rochester led the crowd to the attic, "the lunatic sprang and grappled his throat viciously, and laid her teeth to his cheek" "[4] (Brontë, 280). It is another rebellion against her husband. The last is to burn Thornfield Hall on the ground, fighting against the patriarchal society with her life, desolate and solemn.

But popular prejudice against rebellious and complaint of married women is so great: expressing dissatisfaction or boredom is thought to be extremely unfaithful, ungrateful and unethical. ${ }^{[5]}$ (Greer, 2002, 336) Bertha's retaliatory actions only gave her the appellation "the madwoman in the attic". She never got the chance to speak out her story. Her wordless struggle is the outburst of the oppression under patriarchal culture. Break out in silence or perish in it.

\section{Conclusions}

In the time Jane Austen lived in, women's social status were low and they could not achieve economic independence. Though they may feel frustrated and discontented, they were incapable of fighting. However, In the time Charlotte Brontë lived in, English proletariat was fighting for democratic rights, advocating women's freedom. Women had feminist consciousness and they called for equality between male and female. Due to the time and environment Jane Austen and Charlotte Brontë lived in are different, there are differences of character traits between Elizabeth and Jane Eyre. But both of them advocated that women should have both physical and spiritual independence, not catering men's taste and severing as an appendage. They had great appreciation for gender equality and mutual respect. They fought against the unfairness of society with great courage.

But by contrast, Charlotte Brontë's feminist thoughts are fiercer and bolder. Her desire of pursuing equality is more urgent. Comparing to Elizabeth, Jane Eyre is more vivid, more rebellious. She is a plumper figure of flesh and blood. As a woman writer, Charlotte Brontë's anxiety of identity makes Bertha a representative character struggling against patriarchy insanely. Charlotte Brontë further developed Jane Austen's feminist thoughts. Both of them are excellent women writers, and their works are gems of literary.

\section{References}

[1] Virginia Woolf, A Room of One's Own (Bai Hua Literature and Art Publishing House, China 2002).

[2] Simone de Beauvoir, The Second Sex (China Book Press, China 1998). In Chinese

[3] Jane Austen. Pride and Prejudice (Shanghai World Book Publishing Company, China 2003).

[4] Charlotte Brontë. Jane Eyre (Shanghai World Book Publishing Company, China 2003).

[5] Germaine Greer. The Female Eunuch (Paladin Press, United States 1971). In Chinese

[6] Yanbing Zhang. Feminist Literary Theory (Shandong Education Press, China 1998). In Chinese 